\title{
MODERNIDADE E RAZÃO CRÍTICA EM CESÁRIO VERDE ${ }^{60}$
}

\section{MODERNITY AND CRITICAL REASON IN CESÁRIO VERDE}

\author{
Telma BORGES ${ }^{61}$
}

\begin{abstract}
RESUMO: Este artigo pretende discutir o poema "O sentimento dum ocidental" do poeta português Cesário Verde (1855-1886) como um modo de ler a modernidade na cena urbana, bem como sua relação com Os Lusíadas, de Luís de Camões.
\end{abstract}

PALAVRAS-CHAVE: Literatura portuguesa; Modernidade; Cesário Verde; Camões; Cidade.

\begin{abstract}
This paper aims to discuss about Cesário Verde's poem "O sentimento dum occidental", a Portuguese poet, as a modern way to read modernity in the city and its relation with Os Lusíadas by Luís de Camões.
\end{abstract}

KEYWORDS: Portuguese literature; Modernity; Cesário Verde; Camões; City.

Segundo Jauss (1965 apud MACIEL, 1995, p.7), a expressão "moderno" sugere uma espécie de falácia. Se por um lado é aquilo que está na ordem do dia, que é hodierno, por outro ela tende a se transformar, por sua própria natureza, em seu oposto: o antigo. Essa ambiguidade existe desde que o termo foi usado pela primeira vez, no latim eclesiástico do século $\mathrm{V}$, para marcar a transição da idade romana para a cristã. Conforme Octavio Paz, "a modernidade [no século XVIII] começa como uma crítica da religião, da filosofia, da moral, do direito, da história, da economia e da política. A crítica é seu traço diferencial, seu sinal de nascimento.” (PAZ, 1990, p.34).

Se a crítica é o sinal de nascimento da modernidade, em sua própria concepção há uma oposição: o tempo moderno é um tempo de negação a si mesmo e, ao proceder à sua autocrítica, ele se realiza. Sendo assim, esse tempo se identifica também com a ideia

\footnotetext{
${ }^{60}$ Este artigo é parte de minha pesquisa de mestrado, que resultou na dissertação Uma arqueologia para Cesário Verde, defendida em 2000, na Universidade Federal de Minas Gerais.

${ }^{61}$ Departamento de Comunicação e Letras. Programa de Pós-Graduação em Letras (Estudos Literários) Universidade Estadual de Montes Claros (UNIMONTES) - CEP 39401-036 - Montes Claros - MG Brasil-telmaborges@yahoo.com
} 
de mudança, alterações em todos os planos do saber que conduzem à noção de progresso.

Na medida em que nega a si mesma, de acordo com Paz, a modernidade pode realizar uma operação de volta ao princípio original, cujo retorno só se faz possível na medida em que é feito criticamente. $O$ futuro passa a ser o lugar da perfeição. Busca-se um eterno começo, inventado num presente que se volta para o passado. Mas um passado que aparece de forma fragmentária. Essa operação de volta ao princípio original, de acordo com Paz, só pode ser realizada na modernidade, porque somente ela e apenas ela é capaz de negar a si mesma. (PAZ, 1993, p.61).

Negar-se, mas exercendo sua autocrítica. Criticar-se a si mesma parece ser uma das maneiras de se realizar a modernidade e se entranhar do espírito moderno que, para Baudelaire, é o elemento particular de cada objeto artístico. Ao encontrar uma beleza particular para cada elemento, a modernidade se mostra em sua pluralidade e paradoxalidade.

A experiência estética do século XIX torna clara a duração do provisório, determinada pelo termo. Esse matiz ambíguo do conceito de moderno atinge, nesse mesmo século XIX, seu ponto máximo de reflexão com Baudelaire que, pela via estética, retoma a relação entre "belo universal" e "belo relativo", muito embora os românticos alemães já tivessem sobre ele problematizado ao tratarem da relação entre Romantismo e Classicismo.

No texto "Le peintre de la vie moderne", Baudelaire afirma: La modernité, c'est le transitoire, le transitif, le contingent, la moitié de l'art, dont l'autre moitié est l'éternel et l'immuable. (BAUDELAIRE, 1995, p.852). Na assertiva do poeta francês há uma nítida percepção da conjunção do eterno, antigo e imutável, ao que é hodierno, transitório, contingente. Aqui, moderno não se define por oposição a antigo, mas acena para uma proposta que pretende colocar em diálogo dois momentos distintos por meio dos quais é possível realizar uma crítica do presente. Ou seja, o presente é percebido à luz de uma razão crítica. Disso resulta o surgimento do novo enquanto valor e a mudança que ele opera assume a forma privilegiada da sucessão temporal.

Apropriando-se do conceito cunhado por Baudelaire, Cesário Verde entende o conceito de moderno enquanto uma repotencialização do passado no presente, que só pode ser entendido criticamente na medida em que se observam os vestígios do passado 
como contribuintes na ação constitutiva do presente. Mas num presente que tanto nega o passado quanto se converte numa sucessão de mudanças. Nesse sentido, a percepção que Cesário Verde tem do presente está extremamente distante da visão que dele tem a Geração de 70 portuguesa.

Oliveira Martins, um dos representantes dessa Geração, para quem o organicismo justificava a decadência de Portugal e Espanha, acredita que, assim como a vida de uma nação se desenvolve organicamente, da mesma forma ela se extingue. A partir desse pensamento, para o historiador, seu país tem uma única saída possível:

Cumpre-nos finalmente reconstituir o nosso organicismo social; porque sem ter resolvido as suas questões internas, sem ter conseguido achar uma estabilidade na fortuna, jamais as nações puderam ter uma voz no concerto da humanidade. Sirva-nos de lição e exemplo tudo que observamos na longa decadência da Espanha romana, na lenta elaboração orgânica da Espanha moderna - que afinal, consumada, dá o esplendor do XVI século. Por muitos lados a nossa história de hoje repete a antiga; e meditando-a bem, nós, peninsulares, acaso descubramos nela a prova da existência de uma força íntima e permanente que, libertando-nos da imitação das formas estrangeiras, poderá dar à obra da reconstituição orgânica da sociedade um cunho próprio, mais sólido por assentar na natureza da raça, mais eficaz porque melhor corresponde às exigências da obra. (MARTINS, 1951, p.337; grifos nossos).

Tanto Cesário Verde quanto Oliveira Martins crê que uma possível saída para Portugal está em sua reestruturação interna. Mas as concordâncias encerram-se por aí. Martins acredita que Portugal deverá renascer das cinzas - o presente é visto em função do passado -, fertilizar suas próprias entranhas, abolir as influências estrangeiras, acreditar no espírito da raça, encontrar os novos navegadores, para que a história de amanhã não repita a história de hoje e, por consequência, a de ontem. Essa nova navegação permitirá ao país largar as costas do Velho Mundo em busca de uma nova fisionomia para os tempos vindouros. Redescobre-se a América, enquanto Portugal continua sem a devida compreensão de sua história.

O sucesso dessa nova navegação, para Martins, está reservado aos que foram apóstolos da antiga ideia católica: a conquista de novas terras além-mar para difundir o messianismo, cujo momento máximo foi o século XVI. Ao se repetir todo o processo 
vivido por Portugal nos tempos áureos, torna-se evidente que é impossível não se repetirem as cenas de ontem hoje e as de hoje, amanhã.

Se para Martins o Catolicismo é uma possível saída, Cesário, cuja educação o mantivera distante de tal crença, aponta como saída uma nova epopeia, a ser construída com a "raça ruiva do porvir" (VERDE, 1983, p.70; v.153) ${ }^{62}$, já anunciada na épica camoniana: "Quero que haja no reino neptunino / onde eu nasci, progênie forte e bela (CAMÕES, 1980, p.333; canto IX, v.329-330). Essa raça, fundadora de uma nova cartografia, numa nova nação portuguesa, traz apenas vestígios do passado que se misturam à cena presente, não ressurge das cinzas; reinventa o passado no presente, orientando-se numa outra direção. Esses vestígios são fundamentais para Verde entender seu tempo e fazer prognósticos para o futuro. Não é à toa que o poeta absorve a imagem ocidental, no que ela tem de fragmento, quando da homenagem a Camões no poema "O sentimento dum ocidental".

A atuação desses resíduos, num tempo contingencial, lembra a mônada (BENJAMIN, 1994, p.231) benjaminiana que se faz das ruínas do passado. Esse passado que avança sobre o presente é sempre outro, devido à forma como se dá a sua interação com esse tempo, o que faz do presente um fato "constelar". Entretanto, o poeta não se deixa enganar pela visão que tem desse passado. Seu desejo é evidenciar que a cidade sobre a qual transita não se constitui de um tempo "homogêneo e vazio", mas de uma sucessão simultânea de passados e agoras.

O que Cesário sinaliza com essa percepção da cidade é que é impossível negligenciar o passado em função de um desejo de futuro, uma vez que o presente não se faz sem os fragmentos de outrora e, por consequência, nem o porvir. Para escapar à visão linear da história, Benjamin propõe que o discurso histórico deve dar-se a partir de uma perspectiva constelar - embora dentro de uma concepção messiânico-salvacionista - que agrega tempo e espaço. Em "O Sentimento dum ocidental”, Cesário Verde tem como proposta poética a técnica de sobreposição de cenas, fatos, sentimentos e emoções. Expõe múltiplas vivências conformadas numa dicção que se apropria do tempo presente tal como está evidenciado acima. A partir desse olhar multifacetado, o poeta faz emergir uma nova cartografia poética de Lisboa, bem como do Ocidente por ela representado.

\footnotetext{
${ }^{62}$ Como o poema "O sentimento dum ocidental" será repetidas vezes citado ao longo do texto, optamos por mencionar apenas, daqui por diante, os versos correspondentes a cada citação.
} 
Passo, agora, para uma análise sistemática do poema em questão, com os seguintes objetivos: a) colocar em evidência o perfil moderno e contrastivo da capital portuguesa; b) delinear a ideia de Ocidente proposta pela singularidade crítica do poeta; c) apontar para uma possível arqueologia do futuro aí entrevista.

Cesário Verde (1855-1886), poeta e comerciante, passa longas horas na loja da família, situada à Rua dos Fanqueiros, no centro de Lisboa. Nos momentos de folga, segundo João Pinto de Figueiredo (1986), o poeta costumava tomar lugar à porta da loja e, de lá, observar o movimento das ruas. Seja da porta, seja do balcão, ele, forçosamente, via a inscrição camarária gravada na esquina da Rua dos Fanqueiros: “Rua Nova da Princesa, $1^{a}$ Divisão do lado ocidental" (FIGUEIREDO, 1986, p.29). O adjetivo, com certeza, não poderia ser melhor explorado, pois Verde, efetivamente, encontrava-se do lado ocidental, com todos os sentidos que a palavra carrega. E é desse lugar ocidental que o poeta colhe a matéria-prima para seus versos. Interessante lembrar que, ao falecer, o poeta é sepultado em lápide familiar situada no "Cemitério Ocidental". Cabe saber quais são os sentidos de Ocidente que o poeta expõe, na medida em que vai compondo o seu poema.

1880 é o ano do tricentenário de Camões. Lisboa prepara-se para uma grande festa: cortejos cívicos, carros triunfais, sessões solenes; medalhas são gravadas assinalando a efeméride; no mercado surgem fósforos e biscoitos com o nome do épico; janelas são alugadas para se assistir ao desfile. A festa surgiu como uma atividade transitória, mas lucrativa. Ou seja, criou-se um mercado em função do tricentenário. Até mesmo um bairro é construído e recebe o nome do poeta homenageado.

Toda essa potência especulativa, por mais explícita que seja a efeméride, confere à imagem do poeta épico outra dimensão: ela sai do espaço do bem cultural e ganha a dimensão do bem de consumo. Certamente não passara incólume aos olhos de Cesário Verde toda a comicidade patética do momento, mas nele também colaborou escrevendo versos, possivelmente solicitados por Ramalho Ortigão. Segundo João Pinto de Figueiredo, “'O Sentimento dum Ocidental' não incluía os títulos que hoje o dividem Ave Maria, Noite Fechada, Ao Gás, Horas Mortas - nem tampouco a dedicatória a 
Guerra Junqueiro. Temos, pois, de atribuir tais coisas a Silva Pinto.” (FIGUEIREDO, 1986, p.23). ${ }^{63}$

Mesmo sabendo da possível alteração realizada por Silva Pinto, a análise que ora se apresenta estará baseada na publicação dada a lume pelo amigo do poeta, por ter sido esta a primeira versão a que o público teve acesso e por acreditar que essas peculiaridades são importantes para este estudo.

O poema está estruturado em dois planos: um aberto e um fechado. O plano aberto indica as possibilidades de se construir um pensamento, uma linguagem, uma arqueologia; outro começo que conduza ao futuro. O plano fechado constitui o tempo presente - com toda a carga que traz consigo - no qual o poeta deambula pelas ruas da capital em (re)construção.

$\mathrm{Na}$ medida em que o poema vai sendo enunciado, a noite também vai progredindo. Para Margarida Vieira Mendes (1979, p.47), à medida que a noite e a escrita vão avançando, o desejo mórbido de sofrer vai se adensando; também a quantidade de vida aí representada vai, gradualmente, desaparecendo.

O poeta inicia, porém, sua caminhada em "Ave Maria”, vislumbra ainda alguns trabalhadores em trânsito pelas ruas ou finalizando suas tarefas diárias: carpinteiros, calafates, obreiras, varinas. Contrapostas a esse croqui da vida operária coletiva, imagens da pequena burguesia também freqüentam o cenário: dentistas, lojistas. Esta última imagem lembra o Cesário comerciante, mas que, à porta da loja, flagrava cenas cotidianas, mais tarde exploradas em sua poesia.

A luz natural vai sendo, pouco a pouco, substituída pela luz artificial e a fumaça das chaminés emprestam à cidade um tom melancólico, sombrio. Essa escuridão que subtrai o poeta da vigilância do outro é um modo de confinamento que lhe permite empreender uma poética noturna e deambulante. Há, entretanto, momentos de repulsão a esse confinamento, como se verá adiante. Se a sombra é um modo de torná-lo anônimo, o prolongamento do dia, por meio de uma iluminação artificial, contribui para que vá dissipando, pela sua palavra, audácias inconfessáveis e empreendimentos da civilização que aprisionam o humano.

Em meio a esse cenário nublado, o poeta vê surgir a imagem de Camões, não a do grande épico, mas suas réstias. Aquele que salva seu livro parece tentar salvar

\footnotetext{
${ }^{63}$ Silva Pinto é o grande amigo que, mesmo distante, mantinha contato regular com Cesário Verde. Após a morte deste, reunirá em edição os textos do amigo.
} 
também a pátria portuguesa: "E evoco, então, as crónicas navais: / Mouros, baixéis, heróis, tudo ressuscitado! / Luta Camões no Sul, salvando um livro a nado! / Singram soberbas naus que eu não verei jamais!" (est. 6).

Ao resgatar a imagem de Camões salvando de um naufrágio "um livro", Cesário Verde sugere um mito de origem fundado numa lenda forjadora do destino português, que se garantiria pela literatura. Entretanto, o presente é um cenário sem consistência, nebuloso: nem sustenta a lenda de Camões, cujo monumento a ele erigido está esquecido entre "exíguas pimenteiras" (v.66), nem consegue realizar um diálogo com os grandes centros europeus a partir de sua literatura, pois o projeto de reestruturação da moderna capital estava fundamentado numa relação de apagamento das marcas do passado, além de lançar um olhar especular e não reflexivo para as propostas desses centros.

David Mourão-Ferreira (1994), no ensaio “Cesário Verde e Camões - Uma leitura complementar d'O sentimento dum Ocidental'”, chama a atenção para o fato de Verde aludir a "um livro" e não a "o livro", o que, para o crítico, promove certo rebaixamento ou distanciamento da épica lusíada; "tão pouco sugere a íntima relação entre o sujeito e o objeto da operação de salvamento". (MOURÃO-FERREIRA, 1994, p.83). Assim sendo, o livro afigura-se enquanto uma alusão reticente, carregada de reservas, pois a ênfase está na performance do nadador e não no objeto que salva, perde sua força espiritual: é um livro qualquer.

Na verdade, o poeta não deseja realizar um "rebaixamento" ou "distanciamento" em relação à tradição representada por Camões, mas evidenciar que, ao rasurar essa tradição, paradoxalmente, ela ganha um lugar para reflexão, afinal está esquecida ou perdendo espaço para o processo de ocidentalização já preconizado na própria épica.

Contraposto ao mundo glorioso das "grandes descobertas", está o mundo presente, que encobre ou pelo menos assombra esse passado: "as ancas opulentas" das "varinas" (v.36-37), que se aproximam ritmicamente da expressão "naufragam nas tormentas (v.40), evidenciam esse estado de miséria mencionado por Verde numa carta endereçada a Emídio de Oliveira. A fecundidade dessas mulheres-pilastras gera um sentimento pessimista com relação à miséria dos trabalhadores, o que faz surgir no final da primeira parte do poema os "focos de infecção" (v.44). 
O poema tem como pano de fundo "Le crépuscule du soir", de Baudelaire (1995), e Os Lusíadas, de Camões (1980). Esses avatares literários inserem o texto de Cesário, por um lado, na tradição estética fundada por Baudelaire, que tem como elementos principais a descoberta da lírica da cidade e as figuras humanas que nela transitam: mendigos, prostitutas, bebedores submetidos à servidão de um projeto de modernidade.

Por outro, o poema assume ares de paródia. A referência irônica a Camões, a mercantilização da ocidental praia lusitana, a heroicidade das varinas evidenciam o rebaixamento do épico. Há também a descoberta de um lirismo tensionado pela pulsão afetiva, aberto aos rumores da vida comercial, portuária, das tabernas de emigrados, dos sanatórios, hospitais. Essa antiépica que engendra uma relação entre duas vertentes estéticas desemboca no irônico L'héroisme de la vie moderne:

O heroísmo da vida moderna nos envolve e nos pressiona. [...] Será pintor, um verdadeiro pintor, quem souber tirar da vida atual seu próprio lado épico e nos fazer ver e compreender com a cor e desenho, o quanto nós somos grandes e poéticos dentro de nossas gravatas e nossos calçados envernizados. (BAUDELAIRE, 1995, p.731) ${ }^{64}$.

O tom exacerbado de Baudelaire funda uma poética que atribui o mais elevado lirismo a objetos corriqueiros, que assumem a imagem do ironicamente épico. No caso de Cesário Verde, a grandeza épica das varinas provoca certo incômodo, pois é a expressão antitética dos grandes navegadores da gloriosa épica camoniana: "os barões assinalados" (CAMÕES, 1980, p.23; v.1).

O fim de tarde adensa ainda mais as angústias do poeta, principalmente quando este evoca as "soberbas naus" (v.24) para, logo a seguir, evocar "um couraçado inglês" (v.26). Essa proximidade denuncia o domínio inglês, que culminou no Ultimatum de 1890 .

Os motivos camonianos presentes no poema expressam não só o desejo de se comemorar o tricentenário do poeta épico, mas também a intenção de, pela paródia, denunciar o esquecimento a que Camões ficou relegado. Por isso sua presença é, a um só tempo, sutil e provocadora. Sutil, porque aparece apenas duas vezes: no verso 23 , da

\footnotetext{
${ }^{64}$ L'héroisme de la vie moderne (...) nous entoure et nous presse (...). Celui-là sera le peintre, le vrai peintre, qui saura arracher à la vie actuelle son côte épique, et nous faire voir et comprendre, avec grands et poétiques dans nos cravates et nos bottes vernies. (Tradução nossa).
} 
primeira parte, e no verso 68, da segunda. Na primeira aparição: "luta Camões no Sul salvando um livro a nado!", a consagração do poeta ainda não se fizera notar. Na segunda, “Um épico doutrora ascende, num pilar!”, a imagem do poeta, já historicizada, monumentalizada, está esquecida entre elementos da vida moderna; mistura-se às cenas cotidianas: burguesinhas do catolicismo, os cafés e os corpos enfezados pelo Cólera e pela Febre.

Para Mourão-Ferreira, essa segunda alusão em que já nem se profere o nome de Camões não a torna menos clara. O ensaísta acredita, porém, que a rasura no nome significa afastamento e dessacralização do épico predecessor. Camões torna-se o precursor de Cesário pela negação. Não porque negasse sua importância na história da literatura portuguesa. A denúncia que aí se explicita é a da existência de um espírito coletivo preocupado com incidentes pseudobiográficos e com um desejo de monumentalidade tão-somente. No entendimento de Verde, o povo português via Camões apenas na condição gasosa de um épico de outrora. A grandeza da estátua é épica, mas a obra é apenas um livro, o que talvez justifique o fato de Cesário Verde, ironicamente, não mencionar, em nenhum momento do poema, a obra de Camões propriamente dita, para se deter apenas em fatos isolados e historicamente distantes. Ao, supostamente, negar a épica, o poeta dessacraliza a comemoração, mote do poema, e não a importância de Camões para a literatura.

A segunda aparição de Camões pode ser lida como uma efígie, uma estátua convertida em bronze, monumental. Porém, um monumento que se refere às proporções guerreiras e não ao caráter poético da obra, que é tão somente "um livro" e seu autor um épico de outrora a assombrar o presente. Essa imagem épica e guerreira de Camões ali, se expõe enquanto um signo que tenta manter a lembrança de um passado grandioso. Entretanto, na medida em que se associa ao povo que erra pela cidade e às mazelas das quais ele e o povo são vítimas, percebe-se uma explícita denúncia de um presente que vai, aos poucos, marmorizando seu passado, destruindo sua memória.

A sutil, mas eficaz passagem de Camões pelo poema de Cesário Verde, parece confirmar o que expressa o poeta na carta enviada a Emídio de Oliveira, na qual dizia não poder, por absoluta falta de aptidão, realizar um trabalho artístico especial dedicado a Luís de Camões, mas que fez notar menos mal o estado de pobreza e miséria da 
Lisboa presente em relação ao seu passado grandioso. (OLIVEIRA apud SILVEIRA, 1986, p.17).

Ao ressaltar falta de aptidão para realizar um trabalho especial a Camões, não se entende uma inaptidão ou inapetência, como quer Mourão-Ferreira. Ao contrário, o que está sugerido é que o poeta escreve com toda a carga e influência do passado, mas deseja, através da ironia, ressaltar que o esquecer Camões é passar um atestado de óbito à história portuguesa. Expor o estado de pobreza não significa exumação desse passado grandioso. Antes, significa refletir como o presente se relaciona com o passado e agencia um novo rastro épico, contrastivo e noturno.

O que se afigura é que Verde tem aguda consciência da singularidade da poesia que escreveu. Pode-se captar, ao longo do poema, a afirmação de uma poética inovadora, por isso moderna, adaptada às novas condições técnicas: "A esguia difusão dos vossos reverberos / E a vossa palidez romântica e lunar!" (v.111-112). O título do poema também enceta nessa direção. O sentimento não está colocado como característica: o sentimentalismo de um sujeito isolado. A semântica é de um substantivo: sentimento de um sujeito que se localiza geográfica e poeticamente no Ocidente. Portanto, a adjetivação recai sobre Ocidente. Ser ocidental não é condição exclusiva de um sujeito isolado, mas daquele que se realiza no coletivo.

Diante do exposto, não se pode dizer que Cesário Verde negue uma tradição herdada de Camões. Na verdade, ele não herda essa tradição. Nela o poeta se inscreve crítica e ironicamente por escolha, no desejo de reacender os traços de uma potência literária enfraquecida, rarefeita. Pode-se então dizer que a influência de Camões sobre Cesário Verde assume proporções de denúncia: esquecer Camões ou apenas relembrá-lo em uma efeméride especulativo-capitalista é desconsiderar sua importância literária na história da literatura ocidental.

Entretanto, a ironia que ressoa dos versos de Cesário faz de Camões, não a vítima, mas o modo de atacar aqueles que veem nele apenas uma potência especulativa. Nesse sentido, o poema é o reverso d'Os Lusíadas porque, ao invés de cantar as grandezas épicas, evoca a pobreza e a miséria anti-épicas do presente, da vida moderna.

$\mathrm{Na}$ verdade, a homenagem aí está posta, realizada, e parece ter contrariado a exaltação mítica e nacionalista exalada das outras produções que se fizeram à época. Ao, aparentemente, contrariar os propósitos da homenagem, Cesário Verde cria um 
modo de pertencimento ao Ocidente pela negação, além de se filiar à lírica da modernidade com tudo que ela problematiza. Faz da sua poesia o elo português com o mundo.

A cidade ocidental, pintada por Verde, só existe após o esquecimento do sentido grandioso dos monumentos que ali se amontoam, o que faz emergir uma nova configuração cartográfica. Inseridos na cidade moderna, os monumentos são tragados por um terremoto de signos. Tornam-se virtualmente invisíveis ainda que, em princípio, apareçam para definir e caracterizar uma suposta identidade. São eles também artifícios que intentam garantir a continuidade dessa cidade no tempo.

Enquanto sinal do passado, esse monumento erigido a Camões, como lembrança de um período de glórias, faz parte de uma galeria que assume a função de arquivo; expressa um caráter insistentemente publicitário e anuncia para a impossibilidade de se resgatar o passado no sentido postulado por Oliveira Martins, uma vez que não se preserva nem pela memória, mesmo que ali esteja em forma de fragmentos, vestígios, já que a noção de arquivo vira, enfim, a imagem que constitui o repertório moderno do estado da épica e da poética de uma nação.

Nessa primeira parte, o Ocidente se apresenta enquanto uma chaga exposta que vai, pouco a pouco, sendo encoberta pela escuridão noturna. Essa escuridão, se por um lado encobre as chagas da modernidade, por outro desvenda os sentidos de pobreza e miséria coletivas que se insinuam pelas vias urbanas. Toda essa imagem traduz-se num sentimento melancólico, pois o poeta não enterra o passado, nem consegue conformar seus fragmentos nesse espaço em ebulição.

Na segunda parte, "Noite Fechada", o olhar andarilho do poeta vislumbra os espaços fechados da ocidental terra portuguesa. Aos operários, cabe o desconforto das ruas ou os espaços de confinamento, como as cadeias ou o Aljube, para aprisionar aquilo que macula a imagem do Ocidente.

O sentimento de morbidez, já evidente no primeiro andamento, é intensificado ao acender das luzes que também realçam a silhueta das "prisões, da velha Sé, das Cruzes" (v.51). E, no coração, metonimicamente, cria-se um abismo que é também cartográfico, a evidenciar o hiato criado por duas realidades distintas: "A espaços, iluminam-se os andares / E as tascas, os cafés, as tendas, os estancos / Alastram em lençol os seus reflexos brancos; / E a lua lembra o circo e os jogos malabares.” (est.14). 
Os espaços representados nessa estrofe - os andares, as tascas, os cafés, as tendas e os estancos - alastram e cobrem como um lençol ou, pelo menos, tentam cobrir as expressões de pobreza e miséria representadas na estrofe anterior e no primeiro andamento do poema. Por fim, a lua surge como um elemento do espaço externo, e se presta a duas funções: como malabarista, ilumina não só os espaços burgueses, mas também os de confinamento, tornando ainda mais nítidas as diferenças do cenário urbano. Ela também pode ser pensada enquanto um símbolo contraposto ao cenário artificial, mas que a este ilumina com o intuito de realçar os contrastes da cidade em construção.

Nesse momento em que a imagem dos operários já desapareceu das ruas, o mundo do trabalho dá lugar ao mundo da arquitetura, ao geometrismo urbano no qual o sujeito empírico e poético se vê murado: "Muram-me as construções rectas, iguais, crescidas" (v.62). Esse sentimento de emparedamento aparecerá também ao final do poema "Nós": "Viu o seu fim chegar como um medonho muro" (v.509) e ao longo de todo "O Sentimento dum Ocidental". A sensação de fechamento, segundo Thaís Chaves, é sugerida pelo uso reiterado do grupo fônico /ur/: soturnidade, absurdo, perturba, turba, que se refere ao campo semântico de emparedados. Essa cadeia semântica mescla sensações difusas, de caráter físico e psíquico. (CHAVES, 1993).

Os sentimentos angustiantes, expressos em "neblina", "londrina", "bulício", "maresia", "chaminés", este último remetendo a fumaça e a enjôo, aliam-se ao desejo de extravasamento: toldar-se, extravasar do gás, sombras. O imbricamento dessas sensações elabora uma comunicação entre a intuída angústia e a relação do poeta com os sentidos expressos da cidade.

$\mathrm{Na}$ medida em que sua solitária caminhada avança, as imagens do catolicismo português surgem como nódoas: "Duas igrejas, num saudoso largo, / Lançam a nódoa negra e fúnebre do clero" (v.57-58), que lembram ao poeta a história da Inquisição portuguesa, passado que deseja enterrar, mas que nem mesmo o terremoto foi capaz de fazer desaparecer. Em meio às construções modernas, o "tanger monástico e devoto" (v.64) dos sinos soa como uma mancha sonora incapaz de ser apagada pelo tempo.

A estrofe seguinte, de número 17 , é introduzida pela conjunção adversativa "mas", sugerindo que o olhar do poeta estabelece um contraste entre os espaços arquitetônicos modernos, fechados, descritos na estrofe anterior, e a estátua de Camões: 
Brônzeo, monumental, de "proporções guerreiras", esquecida "num recinto público e vulgar" (v.65-67).

Mas o contraste também é gerado pelo sentido dado a esquecimento. Enquanto, duas estrofes antes, ele deseja esconder uma nódoa do passado: a Inquisição, na estrofe em análise, o sentido épico e guerreiro do poeta d'Os Lusíadas está, ironicamente, alijado entre pimenteiras e bancos de namoro.

Para se somar a esse esquecimento das glórias passadas, o Cólera e a Febre, doenças típicas das más condições de higiene, provocadoras de um pânico coletivo em Portugal e em todo o Ocidente, tornando os corpos enfezados, contrastam não só com o sentido grandioso da escultura de Camões, mas também com os palácios, símbolo da assepsia moderna. Entretanto, a imagem do casebre macula esse desejo. Palácios e casebres convivem em constante tensão.

Mais uma vez, o poeta retorna seu olhar para as alterações da arquitetura da cidade. Na medida em que avança, é possível vislumbrar conventos da Idade Média transformados em quartéis. Essas alterações fazem parte do projeto de reestruturação do traçado urbano, executado no período fontista. E o poeta evidencia que, qualquer que seja o ritmo da sua marcha, é possível vislumbrar as alterações urbanas a marmorizarem a cidade.

Num tom de lamento, ele profere: "Triste cidade! Eu temo que me avives / Uma paixão defunta!" (v.77-78). Mais que um lamento, há um terror de viver preso a esse passado glorioso e pulverizado pela memória pública. Para se contrapor a esse cenário, a imagem de costureiras e floristas descendo dos magasins, símbolo máximo do processo de importação português, causam-lhe sobressaltos.

A percepção aguda do poeta, assim como a do Baudelaire esgrimista, recolhe material para os quadros de sua poesia. A sua luneta encontra sempre motivos para quadros revoltados (v.86). Esse sentimento de revolta fa-lo-á se recolher a um espaço fechado: a brasserie, onde à crua luz joga-se o dominó (v.88).

Nesse segundo andamento, o olhar do poeta se detém nas fachadas arquitetônicas, construções modernas que intentam esconder toda a antiga história ocidental e a ela sobrepor uma imagem uniforme do Ocidente. Ou seja, as fachadas fazem sombra num passado repleto de medos, angústias e glórias. 
No terceiro andamento, "Ao gás”, a noite esmaga pesadamente como uma pedra de dominó. Esse peso refere-se às peças humanas que se arrastam pelos passeios - as impuras - em busca de sobrevida e iluminadas pela luz artificial a emanar dos lampiões a gás. Mais uma vez o sentimento de emparedamento faz-se presente: "Cercam-me as lojas, tépidas" (v.93), que provocam no poeta o delírio da morte: "Eu penso / Ver círios laterais, ver filas de capelas, / Com santos e fiéis, andores, ramos, velas, / Em uma catedral de um comprimento imenso." (est.24).

Em meio a esse cenário mórbido-delirante, o poeta vislumbra a imagem das burguesinhas do catolicismo que, como as freiras - histéricas pela abstinência sexual contrastam com as impuras de ombros quase nus, a se arrastarem pelas ruas em busca de prazer.

Se a imagem dos operários já não mais se manifesta nas ruas, sons e cheiros são reminiscências de uma vida operária que continua noite adentro: um forjador e um padeiro. Nesse terceiro andamento há certa pausa para uma reflexão metalinguística a partir das duas imagens acima, que se colocam no mesmo nível do fazer poético. A forja e o pão, elementos vitais da força e da vida, alinham-se pela aditiva "E" à criação poética: "E eu que medito um livro que exacerbe" (v.105), que o poeta deseja ser resultado do real e da análise.

A partir dessa perspectiva, Margarida Vieira Mendes afirma: "a poesia passa a ser um alimento como o pão e uma fabricação vulcânica como a dos metais". (MENDES, 1979, p.49). Contrariamente, contudo, ao restante de sua obra, na qual o sujeito em cena se afirma enquanto poeta, n' "O Sentimento dum Ocidental" tal assertiva ganha pressuposições hipotéticas e negativas: "Quisera que o real e a análise mo dessem" (v.106) e "Não poder pintar / Com versos magistrais, salubres e sinceros" (v.109-110).

Essa aparente incapacidade de uma fabricação poética dotada de precisão conjuga-se com a dispersão do próprio poema pelo cenário que se deseja flagrar, o que provoca evocações e sensações confusas, evidenciadas pela exploração, no mesmo nível, dos cinco sentidos. A partir de então, torna-se evidente que a poesia não estabelece conexões só com a forja e o pão, mas também com a luz: "vossos reverberos" (v.111), a moda: "Desdobram-se tecidos estrangeiros" (v.121). 
Ao final do terceiro andamento a noite vai, gradativamente, cedendo espaço para um novo dia operário. A luz dos candelabros, assim como a das estrelas, vai pouco a pouco sendo apagada. A cidade em construção recomeça a aparecer com suas "armações fulgentes" (v.128), também a miséria que a ela está agregada, numa relação contrastiva entre o moderno e o antigo: "Pede-me sempre esmola um homenzinho idoso, / Meu velho professor nas aulas de Latim!" (v.131-132).

Nessa terceira parte o Ocidente se desdobra naquele que é visto e naquele que é planejado no compasso e esquadro. Na medida em que um vai soterrando o outro, forjase uma pretensa unidade cujo desejo é se garantir apenas pela reestruturação do traçado arquitetônico.

Às "Horas mortas", as trapeiras surgem e têm o céu como manto. Apagam-se as luzes artificiais. É madrugada. A despeito da clausura que a cidade oferece, o brilho das estrelas ainda pode ser visto. Esse brilho de estrelas aponta para um passado ideal, em que o logos português era o das estrelas que os orientava em busca de novas terras além-mar: "O tecto fundo de oxigênio, de ar, / Estende-se ao comprido, ao meio das trapeiras; / Vêm lágrimas de luz dos astros com olheiras, / Enleva-me a quimera azul de transmigrar." (est.34).

Contraposta à iluminação artificial, a luz das estrelas faz uma brecha na sombra escura, incide sobre as trapeiras, personagens que recolhem o lixo da cidade. Essas estrelas não prenunciam mais um futuro cheio de glórias, mas refletem no presente fragmentário e em ruínas. O poeta, ao perambular por esse espaço, assemelha-se às trapeiras: recolhe o resíduo espalhado pelo labirinto misterioso em que está se transformando a cidade. E, assim, tenta se subtrair desse cenário através do desejo quimérico de escapar à solidão urbana. Ergue os olhos para o céu, mas os retorna rapidamente, olha para baixo, para as coisas pequenas: um parafuso caindo nas lajes.

O barulho do parafuso caindo desperta a sua atenção para a cidade horizontal, que desponta à sua frente, rasteira, pronta a se estender por mais um dia que nega $o$ futuro. Na medida em que perambula, torna-se sensível à leitura de duas cidades: uma reinventada sobre as ruínas circunscritas nesse plano horizontal, as ruas: carpinteiros (v.16), varinas (v.36), mulheres de dom (v.48), mendigos (v.131-132) são imagens que se misturam à cena urbana e, nas ruas, perturbam a hierarquia idealizada pela modernidade. A outra cresce para o alto com gaiolas, viveiros. Cidade esqueleto, que se 
projeta para o céu e se constitui também numa grande inovação: a cidade se constrói na vertical, despontando como ícone máximo da modernidade.

David Mourão questiona que nada, no poema de Verde, enuncia "o mundo que o português criou":

\begin{abstract}
Nem um negro, nem um mestiço, nem um oriental, nem um brasileiro perpassam nas ruas da Lisboa de Cesário; nem um produto ultramarino se vê exposto nas suas lojas; nem um vestígio da ainda então potência colonizadora, ou sequer colonial, se manifesta no mais ínfimo pormenor; os próprios apetites de evasão expressos pelo narrador lírico registam-se num plano de fuga terrestre ("a via férrea") e sob um signo de explícita continentalidade ("Madrid, Paris, Berlim, S. Petersburgo, o mundo!") sem que jamais as estradas marítimas sejam consideradas como alternativa [...] (MOURÃO-FERREIRA, 1994, p.93).
\end{abstract}

Analisado sob outro ponto de vista, torna-se claro que a recusa de Cesário em tocar nesses detalhes que fizeram de Portugal uma grande potência colonizadora é porque o poeta não pensa mais em Portugal nessa dimensão. $\mathrm{O}$ poema se expressa enquanto algo que menciona Portugal ao mencionar o Ocidente, e este, na medida em que destaca Portugal. Não existe mais a centralidade épica. Trata-se de uma constelação de heróis anônimos, ocidentais, portugueses. Enfatiza-se um sentimento ocidental, logo, português, que pontua os passos do poeta em sua trilha de anonimato crescente na noite urbana.

A vida operária recomeça e o poeta segue "como as linhas de uma pauta / A dupla correnteza augusta das fachadas" (v.141-142). Embalado pelas notas da flauta, o olhar multifacetado do poeta observa atentamente as alterações na cartografia da cidade, que apontam para o que ela vai soterrando, não com o intuito de tornar-se objeto arqueológico, mas com a intenção de esquecer.

Além disso, a flauta introduz um suspiro bucólico presente na poesia ocidental desde Teócrito, via Virgílio, trazido para a lírica portuguesa por Sá de Miranda. Não há como negar certa nostalgia da Idade de Ouro, que desperta um desejo de vida eterna, para alcançar uma perfeição que resvala também no passado: "Se eu não morresse, nunca! E eternamente / Buscasse e conseguisse a perfeição das cousas!” (v.145-146). Ao iniciar essa estrofe pela condicional "Se", o poeta se permite sonhar com um futuro familiar entre "castíssimas esposas, / [...] em mansões de vidro transparente" (v.147- 
148). Ao prever as construções que dominariam a modernidade, Cesário Verde nelas encontra um modo de inserir uma família capaz de gerar os filhos que darão nitidez ao futuro: "a raça ruiva do porvir" (v.153).

Nessa raça vindoura são depositadas todas as esperanças de reelaborar a grandeza épica da ocidental praia lusitana, cuja força estaria concentrada capacidade crítica de ler e de escrever o presente. Ao explorar outros continentes, Portugal o faria através de um olhar crítico, sem assimilar tacitamente as produções estrangeiras. Destaca-se, nessa estrofe, uma visão em prospecção de um espaço amoroso tão mitificado quanto a Ilha dos Amores camoniana. Espaço governado por princípios monogâmicos, em tudo opostos aos valores poligâmicos da Ilha mitificada.

$\mathrm{Na}$ estrofe seguinte abandona-se o aspecto prospectivo, para dar lugar ao volitivo: "Eu quero as vossas mães e irmãs estremecidas, / Numas habitações translúcidas e frágeis." (v.151-152), imagem em tudo oposta à grandeza ironicamente épica das varinas. O poeta deixa de lado o terreno do profético, para dar lugar a uma expressão da vontade de continuar existindo numa raça forte, exuberante.

$\mathrm{Na}$ estrofe 40, o poeta retorna de seu sonho e, à semelhança de como fizera na primeira parte, projeta novamente seu sentimento para a coletividade e a sensação de aprisionamento mais uma vez torna-se evidente: "Mas se vivemos, os emparedados, / Sem árvores, no vale escuro das muralhas!..." (v.157-158). O uso das reticências parece reforçar essa sensação de aprisionamento que percorre o poema e faz o poeta, como num delírio, ouvir vozes em busca de socorro.

Para se somar a essa imagem delirante, os corredores nebulosos causam náusea e as tabernas, elevadas à dimensão humana - pois possuem ventres -, devolvem às ruas os tristes bebedores. $\mathrm{O}$ poeta segue, sem receios, finalizando sua caminhada decifradora da cidade e pincela as imagens de fim de noite que despontam diante do seu olhar: dúbios caminhantes (v.168); cães que assemelham-se (sic) a lobos (v.167); guardas que revistam escadas (v.169); as imorais que fumam nas sacadas (v.173-174).

A "massa irregular / De prédios sepulcrais, com dimensões de montes" (v.172173) aprisiona o ser humano, mas pelas suas frestas deixa escapar a "Dor humana" (v.175). A imagem personificada parece extravasar por amplos horizontes, romper com os espaços de confinamento. Mas, amarga como o fel e sinistra como o mar, ela vai e 
vem como as ondas e, às vezes, como estas, também se quebra, deixando suas espumas à beira da praia.

Ao deixar como imagens finais os bebedores embriagados que, com saudade, se sustentam aos bordos das pernas (v.163), e a "Dor humana" comparada a um sinistro mar, o poeta explicita o grande ícone da história portuguesa. O mar, lugar do medo e do fascínio, evidencia nessa estrofe final, quando comparado à "Dor humana", o resultado das aventuras marítimas portuguesas. Ou seja, Portugal, ao buscar o mar para ampliar seus horizontes de dominação, esqueceu-se de louvá-lo e de si mesmo, conservando-se à margem (DELUMEAU, 1996), como diriam os latinos, dado o mistério que o encobre.

Ainda em sua crítica, Mourão-Ferreira destaca a imagem do mar. Para ele, o mar é reduzido à sensação olfativa da "maresia", fugaz imagem do primeiro andamento do poema; desaparece por completo nas $2^{\mathrm{a}}$ e $3^{\mathrm{a}}$ partes, para voltar a aparecer somente no último andamento através das expressões "vastidões aquáticas" e "marés de fel".

Essa presença sutil leva Mourão a concluir que Verde "volta as costas para o mar" e opera por conta própria aquela "descolonização" que se tornaria inevitável e irreversível um século depois. Antecipadamente abdicando de mitos que serviam de suporte à exaltação do "colonial” e do "colonizar" (MOURÃO-FERREIRA, 1994, p.84).

Ora, não se pode negar essa importante percepção do crítico, mas também não se deve esquecer que a realidade histórico-social de Portugal, contemporânea de Cesário, já é a da descolonização, iniciada com a independência do Brasil. Se a carta que acompanha o poema ressalta a intenção do poeta de fazer "notar menos mal o estado presente desta grande Lisboa que, em relação ao seu glorioso passado, parece um cadáver de cidade", há um desejo expresso, não de preservação do passado como um tesouro intocável; o passado que aí se revela é filigrana, sinal visível do invisível, tesouro que deve ser constantemente reescrito. O presente é o momento de se constatar que não se pode reconstruir um passado heroico. Entretanto, pode ser sonhado, ressaltando o que deu certo, o que deve ser perpetuado.

Se a presença do mar n'“O Sentimento dum Ocidental” é algo vago, diluído e fluido como a própria substância de que é composto, é porque o mar não é mais uma saída possível: "tem marés de fel”; o que é ressaltado em Fernando Pessoa: "Ó Mar 
salgado, quanto do teu sal / São lágrimas de Portugal!" (PESSOA, 1950, p.164; v.12). Pessoa parece, também, ter atentado para a imagem das "vastidões aquáticas", por onde seguiriam os conquistadores de um novo império.

A percepção que Cesário Verde tem do mar está relacionada ao seu aspecto prático, mercantil: "baixéis", "escaleres" de um "couraçado inglês", "heróis" e "mouros", "calafates de jaquetão ao ombro", os supostos "barões assinalados" (CAMÕES, 1980, p.29; canto I, v.1) e "as varinas hercúleas e varonis”. Pela via irônica, o poeta resgata as imagens de um mar devassado, que devolve à terra os restos heroicos de sua grandeza épica. Enquanto o poema de Camões tem por tema primeiro a formação do império ultramarino, o poema de Verde faz cessar "tudo que a musa antiga canta", (CAMÕES, 1980, p.30; canto 1, v.23) para evidenciar uma Lisboa que conheceu a glória e também o sentido da palavra decadência.

O mar é, então, aquela vaga, mas feroz lembrança de um passado glorioso, via de acesso a novas terras a serem cristianizadas. Entretanto, era preciso antes cristianizálo, discipliná-lo, cultuá-lo como forma de vencer o medo. Os disformes seres que nele habitavam simbolizavam ameaças temidas por todos, como Adamastor: também conhecido como Cabo das Tormentas, do Medo; depois de dominado sagrou-se da Boa Esperança. Só um povo com propósitos "santos" poderia neutralizar e exorcizar esse medo. Dominou-se o mar; outras terras. Porém, nem mesmo essas conquistas que através dele aconteceram fizeram com que o país se cumprisse, vertente para a qual já apontava Camões em sua épica, Cesário Verde no poema em questão e Fernando Pessoa no Mensagem. Resta cumprir-se, metaforicamente, no império da literatura.

Sobre a terra, Verde realiza sua caminhada noturna, terminando-a diante do mar. Porém, olhar para ele significa uma vitória sobre a sombra do medo. A aurora é a marca de que a terra vai, outra vez, pertencer aos vivos. Diante do mar, esse medo revelado na "Dor humana" é o espectro que, dissipado da noite, no mar é engendrado, pois que constantemente se explicita enquanto imagem do desconhecido sendo noite ou dia, o que se evidencia no canto IV d'Os Lusíadas: "Depois da procelosa tempestade / Noturna sombra e sibilante vento, / Traz a manhã serena claridade, / Esperança de porto, e salvamento: Aparta o Sol a negra escuridade, / Removendo o temor ao pensamento." (CAMÕES, 1980, p.151; canto IV, est.1).

O nascer do dia é saudado pelos marinheiros como esperança de salvação após uma noite de provações, mas é uma esperança que não oferece garantias. Para Cesário 
Verde, tanto o dia quanto a noite provocam o medo. O imenso torvelinho da urbanização se manifesta constantemente enquanto espectro camuflado por construções modernas, pela luz dos lampiões. Se transmigrar, enquanto ação cartográfica, passou a ser uma quimera tanto pelas vias marítimas quanto pelas terrestres, transmigrar para dentro de si é uma possibilidade: território novo, complexo, ocidental, a ser descoberto.

Sendo assim, o Ocidente se configura como uma eterna noite, uma caverna escura e terrível que aprisiona uma multidão de ricos, pobres, velhos, crianças, loucos, prostitutas, bebedores, iletrados e eruditos. Se a poesia não é o modo de libertação desse inferno ocidental, pelo menos é o exercício que ameniza a dor transformada em melancolia.

Na medida em que Portugal avançava no afã de grandes conquistas, rasgava o véu que encobria o Ocidente desconhecido. Como tentativa de acalmar o furioso mar, os tripulantes recitavam o prólogo do Evangelho de São João, que figura no ritual de exorcismo (DELUMEAU, 1996). O ato de exorcizar pode ser entendido como um ritual de busca da luz, a ascese do conhecimento, em detrimento das trevas.

Nessa dimensão, Cesário Verde declara que o impulso humanista permite a Portugal desbravar o mar e revelar o Ocidente à Europa. Pensando com Platão, pode-se dizer que essa ação desbravadora permitiu que o país contemplasse, à luz da razão, o conhecimento e, consequentemente, o poder. Porém, essa mesma luz é ofuscada porque, ao descobrir o outro, Portugal, na intenção de alargar a fé e o império, se esquece de iluminar suas próprias terras que, com o desaparecimento de D. Sebastião, ficam à mercê do império dos Filipes. É o início da derrocada.

Cesário Verde pode ser comparado aos marinheiros das grandes conquistas. Mas, ao contrário destes, navega por uma terra devassada, onde seres humanos, numa imagética que combina servidão e doença - Cólera e Febre -, arrastam para a vala comum: impuras que se arrastam (v.90), moles hospitais (v.91), "burguesinhas do catolicismo" que "resvalam pelo chão" dos "canos" (v.97-98); é a noite tenebrosa. Uma terra em constante transformação, agitada e ferida pela doença da modernização ocidental. Ao deambular por esse cenário, o poeta expõe as diversas imagens da noite, que se insinuam como travessia indesviável - crítica e consciente. Sua percepção desvenda um Ocidente que é o medo, a escuridão, a peste, o confinamento, o mar. 
Múltiplas imagens que, coladas à sua retina, devem ser desmitificadas pelo exercício poético-crítico.

\section{REFERÊNCIAS}

BAUDELAIRE, C. Poesia e prosa. Org. Ivo Barroso. Rio de Janeiro: Nova Aguilar, 1995.

BENJAMIN, W. Magia e técnica, arte e política. Trad. Sérgio Paulo Rouanet. São Paulo: Brasiliense, 1994.

CAMÕES, L. de. Os Lusíadas. Org. Emanuel Paulo Ramos. São Paulo: Cata-vento, 1980.

CHAVES, T. M. V. M. O estilo irônico na obra de Cesário Verde. 1993. Dissertação (Mestrado) - Instituto de Estudos da Linguagem, IEL/UNICAMP, Campinas, 1993.

DELUMEAU, J. História do Medo no Ocidente - 1300-1800: Uma cidade sitiada. Trad. Maria Lúcia Machado. 3.ed. São Paulo: Companhia das Letras, 1996.

FIGUEIREDO, J. P. de. A vida de Cesário Verde. Lisboa: Presença, 1986.

MACIEL, M. E. Vertigens da lucidez: Poesia e crítica em Octavio Paz. São Paulo: Experimento, 1995.

MARTINS, J. P. de O. História da civilização ibérica. Lisboa: Guimarães, 1973.

MENDES, M. V. (Org.). Poesias de Cesário Verde. Lisboa: Seara Nova/Comunicação, 1979.

MOURÃO-FERREIRA, D. Camões e Cesário: uma leitura complementar de 'O Sentimento dum Ocidental' Colóquio Letras, Lisboa: Fundação Calouste Gulbenkian, n.135-136, 1994.

(Dir.). Colóquio Letras: Homenagem a Cesário Verde, Lisboa: Fundação Calouste Gulbenkian, n.93, 1986.

OLIVEIRA, L. A. de. Cesário Verde (Novos subsídios para o estudo da sua personalidade). Coimbra: Nobel, 1944.

PAZ, O. A outra voz. Trad. Wladir Dupont. São Paulo: Siciliano, 1993.

Barral, 1990.

Los hijos del limo: del romanticismo a la vanguardia. 4.ed. Barcelona: Seix

PESSOA, F. Mensagem. 4.ed. Lisboa: Ática, 1950.

1985.

Poemas. Org. Cleonice Berardinelli. 3.ed. Rio de Janeiro: Nova Fronteira,

SILVEIRA, P. da. (Org.). Cesário Verde 1855-1886. Lisboa: Biblioteca Nacional, 1986.

VERDE, C. O livro de Cesário Verde. São Paulo: Verbo, 1983. 
Artigo recebido em 01/05/2011

Aceito para publicação em 30/05/2011 